\title{
Long-term nutrient dynamics in Las Tablas de Daimiel reveal the wetland has undergone enormous functional changes during the last 38 years $(1980-2018)$
}

\author{
Salvador Sánchez-Carrillo1, ${ }^{1,}$, Miguel Álvarez-Cobelas ${ }^{1}$, Martín Merino-Ibarra ${ }^{2}$, Jorge \\ Ramírez-Zierold ${ }^{2}$ and Josep Anton Morguí ${ }^{3}$
}

${ }^{1}$ Departamento de Biogeoquímica y Ecología Microbiana, Museo Nacional de Ciencias Naturales, Consejo Superior de Investigaciones Científicas (MNCN-CSIC), Serrano 115 dpdo, E-28006-Madrid, Spain.

2 Unidad Académica de Ecología y Biodiversidad Acuática, Instituto de Ciencias del Mar y Limnología, Universidad Nacional Autónoma de México, (ICML-UNAM) Circuito Exterior S/N, Ciudad Universitaria, Del. Coyoacán, CP: 04510, Ciudad de México, Mexico.

${ }^{3}$ Institut de Ciència i Tecnologia Ambientales, Universitat Autònoma de Barcelona (ICTA-UAB), Edificio Z Campus de la UAB, 08193 Bellaterra (Cerdanyola del Vallès), Barcelona, Spain.

* Corresponding author: sanchez.carrillo@mncn.csic.es

Received: $31 / 05 / 19 \quad$ Accepted: 17/10/19

\begin{abstract}
Long-term nutrient dynamics in Las Tablas de Daimiel reveal the wetland has undergone enormous functional changes during the last 38 years $(\mathbf{1 9 8 0 - 2 0 1 8 )}$

Wetlands act as nutrient sinks or sources playing a key role in downstream water quality and ecosystem productivity. Despite their importance, wetlands are highly threatened ecosystems and biogeochemical processes are changing in response to several external and internal constrains; however, these functional alterations have not been evaluated in the long term. In this paper we assess the nutrient dynamics (TOC, TN and TP) in Las Tablas de Daimiel in the long-term, through an input-output study using nutrient concentrations and flows measured monthly in the wetland from October 1980 to December 2018. Considering the entire period, on an annual basis Las Tablas de Daimiel was a net source of TOC (467 \% of TOC inputs were exported) and net sink of TN and TP ( $83 \%$ of TN and $92 \%$ of phosphorus were retained and transformed in the wetland). For the longer period of records, mean export loading of TOC was $2177 \mathrm{~g} \mathrm{C} / \mathrm{m}^{2} / \mathrm{y}$, while retention of TN and TP were $62.8 \mathrm{~g} \mathrm{~N} / \mathrm{m}^{2} / \mathrm{y}$ and $5.7 \mathrm{~g} \mathrm{P} / \mathrm{m}^{2} / \mathrm{y}$, respectively. However, since the 1980s nutrient concentration and nutrient import and export trends have changed dramatically as has their seasonality. High TOC export in Las Tablas are probably related to the short circuit existing in the hydrological functioning of the wetland after the 1980s in which outflows are usually disrupted to extend the wetland inundation for longer. TN and TP retentions begin to show signs of exhaustion but currently it is not possible to conclude if the wetland sediments have reached nutrient saturation. During the last 38 years the wetland has undergone similar environmental scenarios several times but the biogeochemical response of the system has never been repeated. This means the time scale of the environmental interactions and the ecosystem responses are unpredictable, and therefore long-term observations are key to understanding how nature will respond to upcoming global change.
\end{abstract}

Key words: nutrient dynamic, degradation, wetland function, carbon, nitrogen, phosphorus

\section{RESUMEN}

La dinámica de los nutrientes en Las Tablas de Daimiel a largo plazo revela que el humedal ha sufrido grandes cambios funcionales durante los últimos 38 años (1980-2018)

Los humedales actúan como sumideros o fuentes de nutrientes y desempeñan un papel clave en la calidad del agua y la productividad de los ecosistemas ubicados aguas abajo. En estos ecosistemas tan amenazados los procesos biogeoquímicos están en continuo cambio como respuesta los impactos externos e internos. Sin embargo, estas alteraciones funcionales no se han 
evaluado a largo plazo. En este trabajo hemos estudiado la dinámica de los nutrientes (TOC, TN y TP) en Las Tablas Daimiel a largo plazo, mediante un balance de entradas y salidas que utiliza concentraciones de nutrientes y caudales medidos mensualmente en el humedal desde octubre de 1980 hasta diciembre de 2018. Teniendo en cuenta todo el periodo, a escala anual Las Tablas fueron una fuente neta de TOC (se exportó el $467 \%$ de las entradas) y un sumidero neto de TN y TP (el $83 \%$ del nitrógeno y el $92 \%$ del fósforo). En este periodo, la carga de exportación media de TOC fue de $2177 \mathrm{~g} \mathrm{C/ \textrm {m } ^ { 2 } / a n ̃ o}$, mientras que la retención de TN y TP fue de $62.8 \mathrm{~g} \mathrm{~N} / \mathrm{m}^{2} /$ año y $5.7 \mathrm{~g} \mathrm{P} / \mathrm{m}^{2} /$ año, respectivamente. Sin embargo, las tendencias en la concentración de nutrientes y en su importación y exportación cambiaron drásticamente desde 1980, haciéndolo también su estacionalidad. La elevadisima exportación de TOC en Las tablas probablemente esté relacionada con el cortocircuito en el funcionamiento hidrológico que sufre el humedal desde la década de 1980, pues las salidas se han interrumpido para expandir la inundación del humedal por más tiempo. Las retenciones de TN y TP comienzan a mostrar signos de agotamiento, pero actualmente no es posible concluir si los sedimentos del humedal están ya saturados de nutrientes. Durante los últimos 38 años, el humedal ha experimentado escenarios ambientales similares varias veces, pero la respuesta biogeoquimica del sistema nunca ha sido la misma. Debido a que la escala temporal de las interacciones ambientales y las respuestas de los ecosistemas son impredecibles aún, las observaciones a largo plazo son claves para comprender cómo la naturaleza responde a las próximas nuevas condiciones globales.

Palabras clave: dinámica de nutrientes, humedal, degradación, función del humedal, carbono, nitrógeno, fósforo

\section{INTRODUCTION}

In ecology, historical trends are key to understanding the present and anticipating the future. Observation of long-term change is central to our understanding, yet some ecological trends take place at scales that match or exceed human lifetimes (Hobbie et al., 2003). Wetlands play a key role in the landscape through several biogeochemical processes, acting as sinks or sources of nutrients which have a significant impact on downstream water quality and ecosystem productivity (Mitsch \& Gosselink, 2007). Wetland biogeochemical processes are constantly changing in response to external and internal constraints (Carvalho \& Kirika, 2003; Søndergaard, 2007). Knowledge of how the wetland responds to the inputs of carbon, nitrogen and phosphorus is fundamental in order to design successful environmental management plans, thereby reducing uncertainty. However, studies of wetland nutrient dynamics are often short-term and these functional changes are not easily recognizable. Long-term studies of nutrient dynamics in lakes are becoming more common (e.g. Carvalho \& Kirika, 2003; Gerson et al., 2016; Xu et al., 2017) but are still unusual in wetlands (e.g. Day et al., 2006; Bhomia \& Reddy, 2018). How these multiple stressors modulate nutrient processes in wetlands is still little known.

Nutrient input and output or "black box" studies have been a common tool to assess nutri- ent dynamics in aquatic biogeochemistry since the 1960s, mainly in stream ecology (Mulholland \& Webster, 2010). Nutrient budgets have been used to assess the nutrient sink/source of a water body according to the season or to changes in other environmental variables such as hydrology, land use-land cover or wastewater discharge (Likens et al., 1970; Kadlec \& Knight, 1996; Pelster et al., 2008). Although this type of reductionist approach fails to provide detailed mechanistic concepts of how the system properties and processes change, it has been successful in unravelling the basic processes which govern freshwater systems (Heathwaite, 2010). Time-course changes in the nutrient source/sink profile of a wetland are good indicators of their ecosystem services (Zedler \& Kercher, 2005) and can be used to assess the main effects of ecosystem conservation status and basin management plans on ecosystem functioning in the long-term.

Since the 1970s many wetlands have undergone gradual eutrophication, mainly through agricultural runoff and wastewater. In semi-arid regions fluctuations in hydrological conditions induce changes in nutrient inputs and these changes directly modify or change biological communities (Mitsch \& Gosselink, 2007). These complex interactions alter nutrient dynamics but the scope of these changes is not well understood. Las Tablas de Daimiel National Park (TDNP hereafter) is a wetland located in central Spain, which survives from an extended flood- 
plain wetland area covering $150-250 \mathrm{~km}^{2}$ in 1900 (Sánchez-Carrillo et al., 2010). This wetland is a good example of how several types of impact have collectively altered wetland structure and function (Sánchez-Carrillo \& Angeler, 2010). Human impact was moderately low until the 1950s, after which stronger anthropogenic impact occurred (Álvarez-Cobelas et al., 2001). The wetland has been partially drained, channeled, cultivated, burned and later protected (National Park), dammed and artificially inundated. Additionally, the wetland hydrology was deeply altered due to exacerbated groundwater overexploitation and external inputs from agricultural runoff and raw wastewater, causing wetland eutrophication (Sánchez-Carrillo et al., 2010). The most dramatic changes occurred up until the 1980s, after which several environmental management strategies were implemented to restore and preserve the main wetland environmental values (Cirujano et al., 2010). The success of these plans has been limited; the main limitation being water availability, which is as yet unsolved. Recently the region experienced a longer wet period which partially recovered

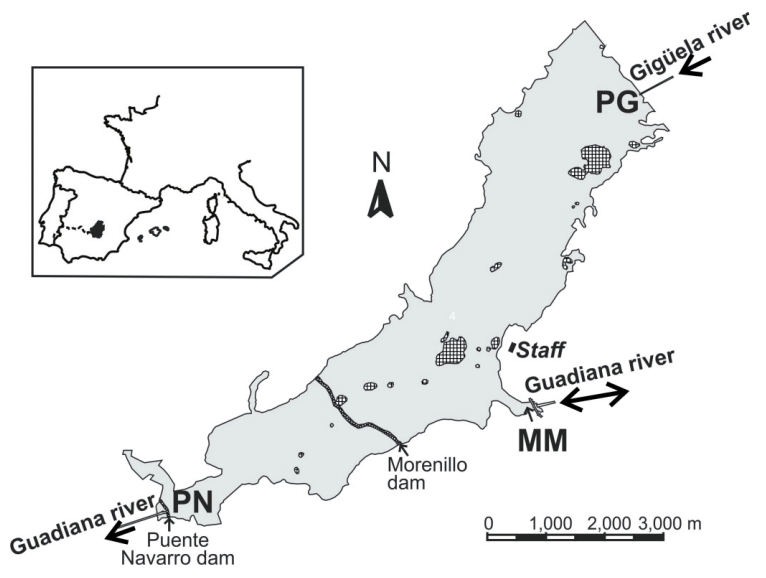

Figure 1. Location of Las Tablas de Daimiel and the inlet and outlet sampling sites considered in this study: PG (Pata Gallina; inlet), MM (Molemocho; inlet/outlet) and PN (Puente Navarro; outlet). Arrows indicate water flow direction at each sampling site. Ubicación de Las Tablas de Daimiel y de los puntos de muestreo considerados para este estudio: PG (Pata Gallina, entrada), MM (Molemocho, entrada/salida) y PN (Puente Navarro, salida). Las flechas indican la dirección del flujo de agua en cada punto de muestreo. previous aquifer overdrafting (Martínez-Santos et al., 2018). In recent years wetland inundation reached maximum values although seasonal patterns differ greatly from those registered 40 years ago. This study aims to advance our understanding of nutrient dynamics in TDNP in the long-term, using records of nutrient concentrations and flows measured monthly in the wetland from October 1980 to December 2018. The main goals of the paper are: (i) to evaluate the changes and trends in total organic carbon (TOC), total nitrogen (TN) and total phosphorus (TP) concentrations observed at the inlet and outlet sites of the wetland over the last 38 years, (ii) to compute monthly and annual water and nutrient budgets in the wetland in order to evaluate seasonal changes and long-term trends and (iii) to consider these trends in the context of wetland dynamics in order to identify the possible drivers of the observed trends.

\section{MATERIALS AND METHODS}

\section{Site description}

TDNP is a semiarid floodplain wetland located in central Spain $\left(39^{\circ} 08^{\prime} \mathrm{N}, 3^{\circ} 43^{\prime} \mathrm{W}\right.$; Fig. 1). The maximum inundated area is $18 \mathrm{~km}^{2}$ with an average water depth of $0.90 \mathrm{~m}$. TDNP is situated at the outlet of a $13000 \mathrm{~km}^{2}$ catchment that overlays a $5000 \mathrm{~km}^{2}$ aquifer. The wetland's hydrology is currently fluctuating, with long drought periods associated with the lack of groundwater discharges due to aquifer overexploitation (Sánchez-Carrillo \& Álvarez-Cobelas, 2010). Nutrient dynamics have been characterized by low discharge, high allochthonous, organic sewage loads, and upland intensive agricultural use, resulting in a hypertrophic ecosystem (Álvarez-Cobelas \& Cirujano, 1996; Sánchez-Carrillo \& Álvarez-Cobelas, 2001; Álvarez-Cobelas et al., 2010). From 2004 to 2009 the wetland experienced one of the greatest droughts recorded in the last 50 years, and a peat fire threatened to destroy the entire wetland. Subsequently (2010-2016) the ecosystem experienced the highest mean annual water-level recorded in the last 40 years. The Gigüela River (also labeled as Cigüela River) has been the only water input to TDNP since 1984 when the springs 
located at the Ojos del Guadiana dried up; however, since 2012 groundwater levels rose as some springs in the Guadiana riverbed recovered and also fed the wetland.

The soils of TDNP are slightly saline $\mathrm{SO}_{4}$-rich histosols and many areas have high organic matter content. The soil is mainly dominated by sand and silt (40-60\% each), with clay comprising only a minor proportion (5-20\%; Rodríguez-Murillo et al., 2011). The species Phragmites australis (Cav.) Trin. ex Steudel (common reed) and Cladium mariscus (L.) Pohl (cut sedge) dominate ( $>90 \%$ cover) the wetland in high flood periods. However, cut sedge, the least productive emergent species in the TDNP (Álvarez-Cobelas \& Cirujano, 2007), is in serious decline. When inundation is low for long time periods most of the wetland area is colonized by terrestrial plants (scurvy grass and horseweed), which cover most of the non-vegetated dry wetland zones in spring and summer, respectively. Las Tablas de Daimiel is a LTER-Spain site included in LTER-Europe networks (https://deims.org/3f485cdb-fd8c-433a-910b$7 \mathrm{f} 8 \mathrm{c} 73 \mathrm{c} 1 \mathrm{~d} 882$ ). Further information about this wetland can be found in Sánchez-Carrillo \& Angeler (2010).

\section{Data collection, sampling procedures, filling gap methodology and statistical analyses}

Two dams retain inundation within the wetland (Fig. 1). The first, Morenillo dam, lying in the central part, is porous and thus allows water exchange with the southernmost area. The second, Puente Navarro dam, located at the end of TDNP, allows water level regulation through a floodgate. Three sampling sites were considered in this study (Fig. 1). Pata Gallina site (PG), located at the NE inlet, represents the inflows from the Gigüela River. Molemocho site (MM), a central inlet/outlet, situated at the inflow of Guadiana River, was the site receiving inflows from the nearby spring Ojos del Guadiana, the main water source of the wetland until 1984, but it was also an outlet site in the period 1997-2012 as a result of geological subsidence by groundwater overexploitation in the area; after 2012 the site again received inflows from recent springs arising in the ancient Guadiana riverbed (Martínez-Santos et al., 2018). Puente Navarro dam (PN), the terminal outlet, represents the outflow from TDNP, downstream Guadiana River, which occur through a floodgate when the inundation in the southernmost part reaches more than 450 ha, although it can also be manually regulated.

Data on water chemistry, flows and inundation were collected from different sources in order to complete the time series shown in this study. Our own data on water chemistry were used for the period 1992-2012. Data before 1992 were collected from Sáez-Royuela (1977), INYPSA (1990) as well as unpublished data from TDNP staff and ICONA. For the period 2012-2018 data were provided by the Laboratory of the Guadiana Water Authority (CHG Lab). Data on flow were our own (1996-2001), of the CGH (Gigüela River, Guadiana River until 1984 and Puente Navarro) and from the Spanish Geological Survey (IGME, which measured monthly groundwater discharges in the new springs emerging from the Guadiana riverbed from 2012 to 2018). Inundation records were provided by the TDNP staff. Water sampling for chemical analyses was in all cases as follow: samples were collected with Niskin bottles (for total nitrogen $-\mathrm{TN}-$ and total phosphorus $-\mathrm{TP}-$ ) or BOD borosilicate glass vials (for total organic carbon - TOC -) and preserved below $4{ }^{\circ} \mathrm{C}$ during field trips which were immediately analyzed in the laboratory. In all cases TOC analyses were measured through high temperature catalytic combustion and infrared photometry (Shimadzu Model TOC-500A). In our samples TN was analyzed following the method of Bachmann \& Canfield (1996) and TP according to standard methods (APHA 2005). Samples analyzed in CHG Lab for TN and TP were measured by combustion/chemiluminescent and inductively coupled plasma optical emission spectroscopy (ICP-OES), respectively. During 2012 (6 times) sampling of both laboratories was overlapped and procedures were compared with differences below $3.7 \%$ in all cases.

Data interpolation was used to fill gaps in all temporal series. Gaps varied from 1 to 5 monthly data with nutrient time series having the longest gaps (up to 12 consecutive months). Gap filling 
methods applied here include: (i) linear interpolation between the values adjacent to the missing value, which was used for small gaps (1-2 monthly values); (ii) mean variation of previous periods (the same month in previous years) in order to include any seasonal trend; (iii) looking for analogous meteorological and hydrological conditions as recorded in the gaps using look-up tables and assuming that environmental conditions are the driving force of the variable and therefore nutrient concentration should be similar; and (iv) regression methods which were used to assess flow based on inundation (MM-flow with rising inundation $\left(\mathrm{m}^{3} / \mathrm{s}\right)=-1.34 * \mathrm{LN}$ Inundation (ha) $+6.52 \mathrm{R}^{2}=0.92 p=0.001$; MM-flow with decreasing inundation $\left(\mathrm{m}^{3} / \mathrm{s}\right):=-2.26^{*} \mathrm{LN}$ Inundation $+13.56 \mathrm{R}^{2}=0.82 p=0.01$; PN-flow $\left(\mathrm{m}^{3} / \mathrm{s}\right)=105 *$ Inundation ${ }^{2}-0.03 *$ Inundation + $15.9 \mathrm{R}^{2}=0.63 p=0.02$ ), and to compute TOC from organic matter and this from conductivity data $(\mathrm{MM}-\mathrm{TOC}(\mathrm{mg} \mathrm{C} / \mathrm{l})=[1.36 *$ Conductivity $(\mu \mathrm{S} / \mathrm{cm})-532.74] / 2, \mathrm{R}^{2}=0.69, p=0.01 ;$
PG-TOC $=[1.04 *$ Conductivity +7.82$] / 2 \mathrm{R}^{2}=$ $0.98 p=0.001 ;$ PN-TOC $=1.0 *$ Conductivity + 104.71, $\mathrm{R}^{2}=0.99, \mathrm{p}=0.001$ ).

The Shapiro Wilk's W test was used to assess normality. Data were log- or square root-transformed when non-normal. Pearson correlation was used to find statistical relationships among variables. No flow situations (0 values) were removed circumstantially from the time series to allow correlations using log-data. Outliers were not eliminated during statistical analyses. All data analyses were undertaken using Statistica 7.0 (Statsoft Inc.).

\section{RESULTS}

\section{Inundation and flow trends}

Wetland inundation fluctuated greatly during the entire observation period (Fig. 2a). Mean inundation was $691 \mathrm{ha} /$ month but $56 \%$ of time values were below this average (62\% of monthly
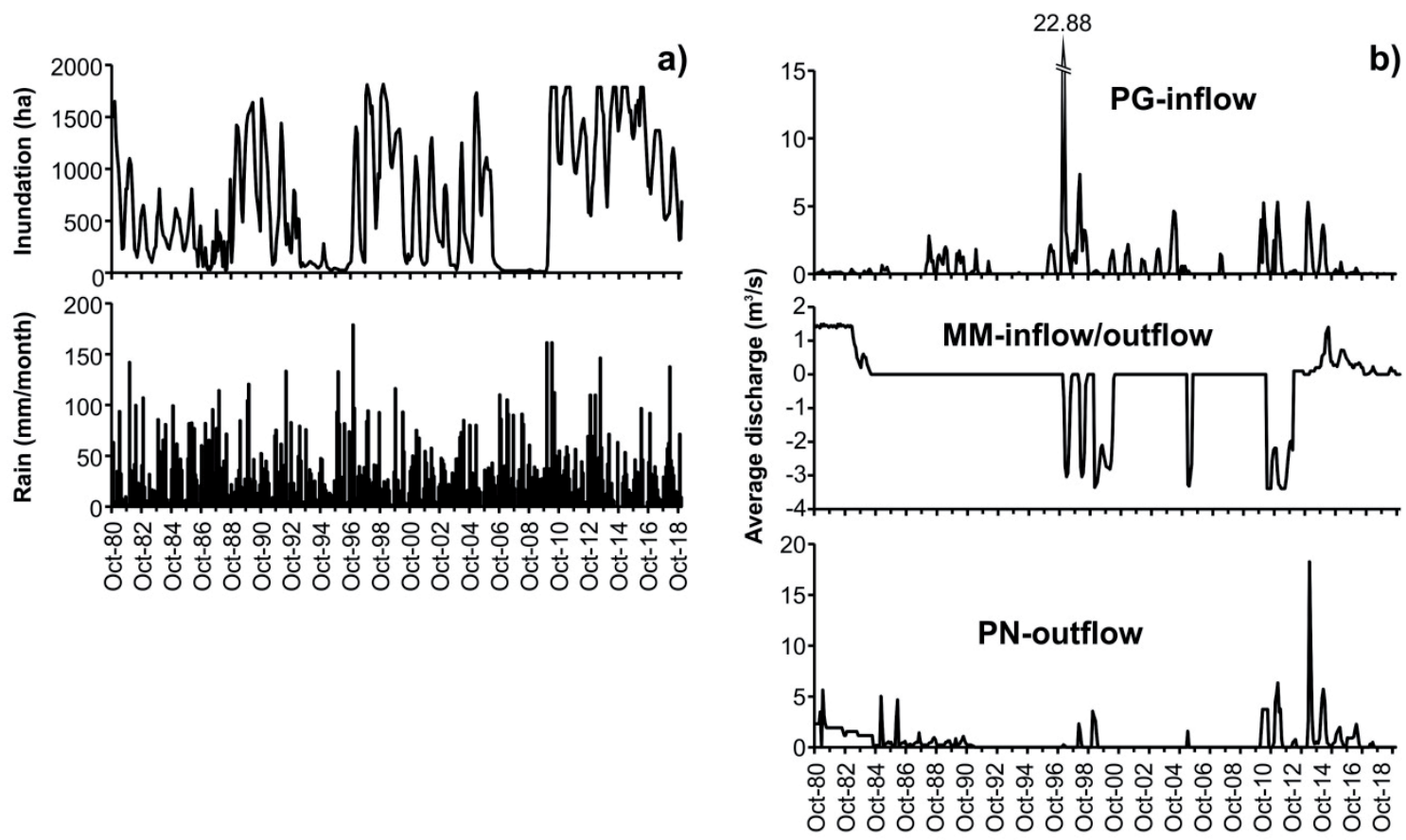

Figure 2. Time course of monthly inundation and rainfall (a), as well as inflows and outflows (b) measured in TDNP for the period October 1980 - December 2018. Curso temporal de la inundación y la lluvia (a) y de los caudales de entrada y salida (b) en TDNP para el periodo comprendido entre octubre 1980 y diciembre 2018. 
Table 1. Average $( \pm \mathrm{SD})$ concentrations of TOC, TN and TP measured at the inflow and outflow sites of Las Tablas de Daimiel for the whole observation period and for each decade. MM site acted as inflow during the periods 1980-1984 and 2012-2018, but was an outflow site from 1997-2011. Concentraciones promedio ( \pm desviación estándar) de COT, NT y PT medidas en los sitios de entrada y salida de agua de Las Tablas de Daimiel para todo el periodo de observación y para cada década. MM fue como punto de entrada de agua en los periodos 1980-1984 y 2012-2018, y de salida de 1997-2011.

\begin{tabular}{llccccc}
\hline & & $1980-2018$ & $1980-1989$ & $1990-1999$ & $2000-2009$ & $2010-2018$ \\
\hline \multirow{3}{*}{ PG- inflow } & TOC (mg C/l $)$ & $41.7 \pm 125.8$ & $127.8 \pm 236.5$ & $5.6 \pm 4.3$ & $5.2 \pm 2.0$ & $22.0 \pm 18.5$ \\
& TN (mg N/l) & $5.6 \pm 6.2$ & $11.2 \pm 10.3$ & $5.1 \pm 3.3$ & $4.4 \pm 1.6$ & $3.0 \pm 1.3$ \\
& TP (mg P/l) & $2.20 \pm 7.78$ & $8.42 \pm 14.23$ & $0.4 \pm 0.84$ & $0.3 \pm 0.57$ & $0.13 \pm 0.07$ \\
\hline \multirow{3}{*}{ MM-in/outflow } & TOC & $153.6 \pm 148.9$ & $119.1 \pm 1.2$ & $299.4 \pm 136.3$ & $273.2 \pm 97.8$ & $6.3 \pm 6.3$ \\
& TN & $5.6 \pm 3.5$ & $11.4 \pm 2.5$ & $3.5 \pm 1.5$ & $3.5 \pm 2.2$ & $5.7 \pm 2.0$ \\
& TP & $0.17 \pm 0.19$ & $0.09 \pm 0$ & $0.31 \pm 0.31$ & $0.18 \pm 0.18$ & $0.11 \pm 0.08$ \\
\hline \multirow{3}{*}{ PN-outflow } & TOC & $248.0 \pm 216.4$ & $321.6 \pm 64.6$ & $301.9 \pm 86.1$ & $502.7 \pm 277.8$ & $16.8 \pm 6.0$ \\
& TN & $3.4 \pm 2.1$ & $3.9 \pm 1.5$ & $3.1 \pm 1.6$ & $5.2 \pm 2.9$ & $1.9 \pm 0.9$ \\
& TP & $0.15 \pm 0.18$ & $0.09 \pm 0.01$ & $0.2 \pm 0.29$ & $0.31 \pm 0.26$ & $0.1 \pm 0.07$ \\
\hline
\end{tabular}

records were below 900 ha of wetland inundation, around $50 \%$ of the maximum inundation). Meanwhile $22 \%$ of the time wetland inundation was below 100 ha during the whole study period. During two periods, inflows diverted from the Tagus River basin gave rise to high water levels in the wetland (1988-1992, 2000-2004; Fig. 2a). Rainfall recorded in Las Tablas from 1980-2018 was on average $370 \pm 103 \mathrm{~mm} / \mathrm{yr}$. Time-course trends were not observed in the rainfall time series (Fig. 2a) nor was any significant relationship found with wetland inundation $(p>0.05)$. Inflow recorded at the Gigüela River in the wetland inlet was on average $0.55 \pm 1.52 \mathrm{~m} 3 / \mathrm{s}$ for the whole period; maximum discharge was recorded in February 1997 (20.88 m3/s; Fig. 2b). Average outflow at the outlet PN site was $0.61 \pm$ $1.42 \mathrm{~m} 3 / \mathrm{s}$; peak was registered in April 2013 $\left(18.25 \mathrm{~m}^{3} / \mathrm{s}\right.$; Fig. 2b). No water inflows were recorded at the PG site $44 \%$ of the time while the wetland did not release water by the PN outlet site $56 \%$ of the time (Fig 2b). During the 38-year period, the MM site mainly functioned as an outlet site, extracting water from the wetland at a mean rate of $0.16 \pm 0.99 \mathrm{~m}^{3} / \mathrm{s}$. At this $\mathrm{MM}$ site maximum inflow was $1.49 \mathrm{~m}^{3 / \mathrm{s}}$ (April 1981) whereas maximum outflow was $3.39 \mathrm{~m}^{3} / \mathrm{s}$ (April 2010; Fig 2b). MM registered no flow during $64 \%$ of the time (Fig. 2b). Monthly inflows and outflows marginally explained the variance in wetland inundation $\left(\mathrm{R}^{2}=0.06 p=0.001\right)$; on an annual scale, inflows explained only $14 \%$ and $21 \%$ of variance in mean and maximum inundations ( $p=0.02$ and 0.003 , respectively). Outflows improved the mean annual inundation prediction to some extent $\left(\mathrm{R}^{2}=0.36 p=0.0001\right)$.

\section{Nutrient concentration variability and month- ly nutrient budgets}

Nutrient concentrations at the inlet and outlet sites of the wetland for the entire study period are shown in Table 1. While TOC concentration increased $494 \%$ from the inlet site to the outlet site, TN and TP concentrations decreased $40 \%$ and $93 \%$, respectively. At the PG-inlet site, TOC concentration decreased strongly from the $1980 \mathrm{~s}$ to the first decade of 2000 and then increased slightly in the last decade, i.e., 2010-2018. At MM site, TOC concentration was more variable, but decreased notably in the $2010-18$ cycle $(95 \%$, Table 1). At the PN-outflow site, TOC concentration increased in the 2000-2010 period but dropped greatly from then on (95\% from 1980s). Downward trends in $\mathrm{TN}$ concentrations were observed at all sites with distinctive patterns (73\%, $50 \%$ and $51 \%$ in PG, MM and $\mathrm{PN}$, respectively; Table 1). TP concentrations exhibited a $98 \%$ reduction in $\mathrm{PG}$, while at the other sites, which exhibited lower initial concentra- 

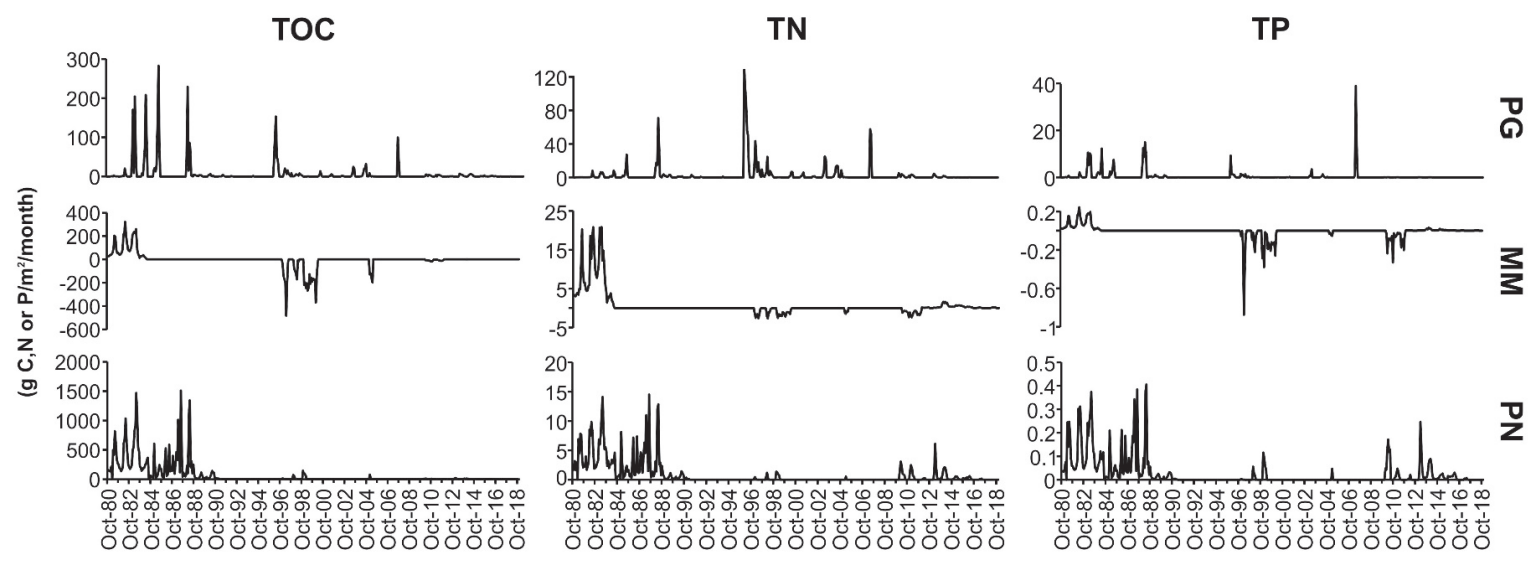

Figure 3. Monthly input and output loadings of TOC, TN and TP measured at the inlet (PG and MM) and outlet (PN and MM) sampling sites in Las Tablas de Daimiel from October-1980 to December-2018. Cargas mensuales de entradas y salidas de COT, NT y PT medidas en los puntos de entradas (PG y MM) y salidas (PN y MM) de agua de Las Tablas de Daimiel desde octubre-1980 a diciembre-2018.

tions, TP increased from the 1980 s to the first decade of 2000, after which it returned to the initial recorded concentrations (Table 1). Relationships between nutrient concentrations and flows were only significant in MM when this site acted as an inlet $\left(\mathrm{R}^{2}=0.49\right.$ and $\mathrm{R}^{2}=0.21$ for TOC and TN; both $p=0.0001)$.

For the whole period, the average external loading of TOC provided by the Gigüela River was $6.67 \pm 27.75 \mathrm{~g} \mathrm{C} / \mathrm{m}^{2} /$ month while the average output loading of TOC released by the wetland from the PN dam was $71.93 \pm 199.49 \mathrm{~g}$ $\mathrm{C} / \mathrm{m}^{2} /$ month. This indicated a monthly mean exportation of $978 \%$ of TOC inputs. On average, data indicated that the MM site acted as outflow with a loading of $3.07 \pm 64.71 \mathrm{~g} \mathrm{C} / \mathrm{m}^{2} /$ month. Trends in TOC loads displayed a strong reduction for the entire period (Fig. 3). The mean TN input loading from the Gigüela River was $2.70 \pm 11.27 \mathrm{~g}$ $\mathrm{N} / \mathrm{m}^{2} /$ month; for the whole period, contrarily to the TOC findings, the average of TN loading indicated that the MM site acted as input site providing an external loading of $0.68 \pm 3.16 \mathrm{~g}$ $\mathrm{N} / \mathrm{m}^{2} /$ month to the wetland. TN output loading was on average $73 \%$ lower than total inputs $(0.91$ $\pm 2.14 \mathrm{~g} \mathrm{~N} / \mathrm{m}^{2} /$ month). Trends in TN input loadings from the Gigüela was highly variable but exhibited a strong reduction after the 1990s (Fig. 3 ); variability on TN loadings measured in MM and PN sites decreased considerably too (Fig. 3). Finally, mean TP inputs were higher $(0.51 \pm 2.53 \mathrm{~g}$ $\mathrm{P} / \mathrm{m}^{2} /$ month $)$ than TP outputs $(0.01 \pm 0.07$ and $0.03 \pm 0.06 \mathrm{~g} \mathrm{P} / \mathrm{m}^{2} /$ month, for $\mathrm{MM}$ and $\mathrm{PN}$, respectively) with an average retention of $91 \%$. Temporal patterns in TP loads were indecipherable (Fig. 3). Significant relationships among nutrient loads at monthly scales were only found for TOC vs TN in MM site $\left(\mathrm{R}^{2}=0.42 p=0.001\right)$ and $\mathrm{PN}\left(\mathrm{R}^{2}=0.52 p=0.001\right)$. On a monthly basis, input and output budgets for the entire study period show that the wetland was a sink for $42 \%$ of surface water $\left(1.57 \mathrm{vs} 0.90 \mathrm{hm}^{3} /\right.$ month of inputs and outputs, respectively), for $70 \%$ of TN (3.54 vs $1.07 \mathrm{~g} \mathrm{~N} / \mathrm{m}^{2} /$ month) and for $92 \%$ of TP (0.51 vs $0.04 \mathrm{~g} \mathrm{P} / \mathrm{m}^{2} /$ month), whereas was a source of TOC ( $427 \%$ of inputs were exported: 15.98 vs $84.31 \mathrm{~g} \mathrm{C} / \mathrm{m}^{2} /$ month).

\section{Seasonal patterns and their long-term changes}

Seasonal trends for inundation and nutrients are summarized in Fig. 4. For the entire study period, seasonal inundation trends peaked in February-March with lowest values during August-September, ranging from 501 to 928 ha, although records show a large inter-annual variability $(\mathrm{CV}$ : from $63 \%$ to $111 \%$ in January and June, respectively). Mean values revealed TOC output load- 
ings (PN) and $\mathrm{TN}$ and $\mathrm{TP}$ input loadings (PG) show strong seasonality which is decoupled from inundation trends. On average, trends for TOC export in PN as well TN and TP imports peaked jointly in June but showed a time lag with the

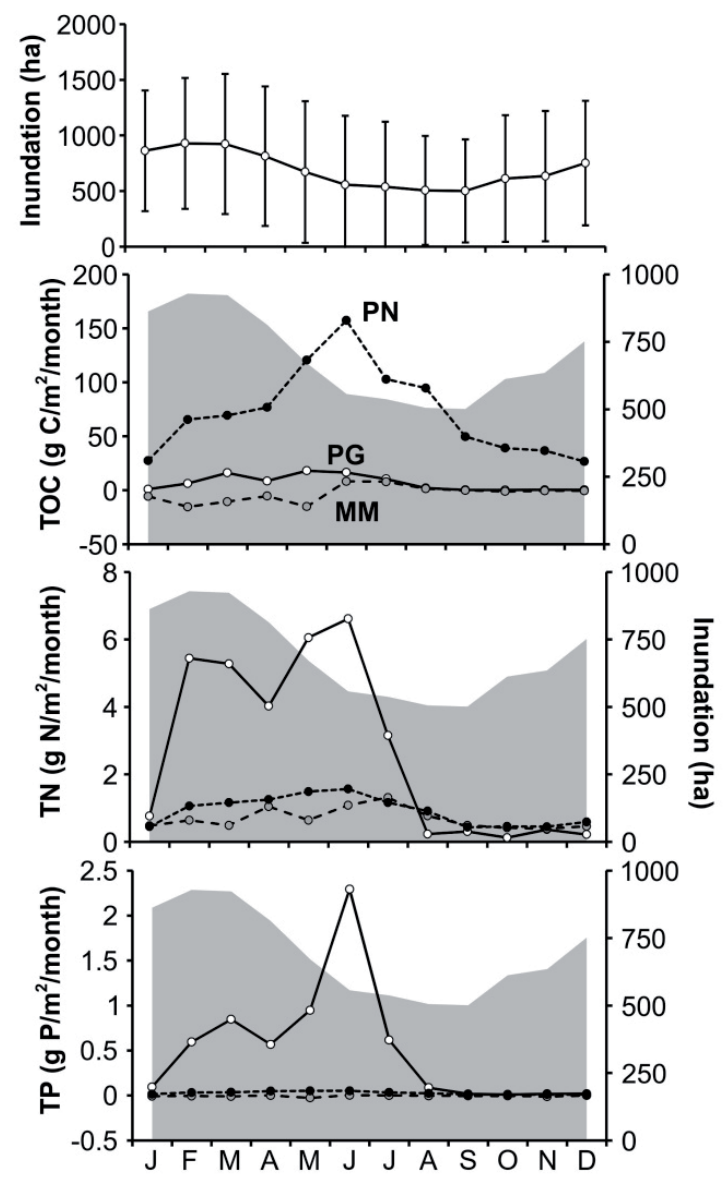

Figure 4. Seasonal pattern of monthly mean inundation (vertical bar is SD) and monthly loadings of TOC, TN and TP in Las Tablas de Daimiel for the whole period 1980-2018. Loadings at PG, MM and PN, the inlet and outlet sites, are shown using lines while the grey area is the mean inundation area for the entire period. SD of loadings were not represented in order to improve graph clarity but can be partially extracted from Fig. 5. Patrones estaciones de la inundación media (la barra vertical es la desviación estándar) y de las cargas mensuales de COT, NTy PT en Las Tablas de Daimiel para todo el periodo de estudio (1980-2018). Las cargas en PG, MMy PN, los puntos de entrada y salida del agua, se han representado con líneas mientras que la inundación promedio se muestra como el área gris de fondo. Las desviaciones estándar de las cargas no se han representado para mejorar la claridad de los gráficos, pero están representadas parcialmente en la Fig. 5. average inundation. However, TOC loadings in $\mathrm{MM}$ significantly matched inundation $\left(\mathrm{R}^{2}=0.53\right.$ $p=0.007)$.

For the whole period, seasonality of water inputs and outputs agreed well with the mean
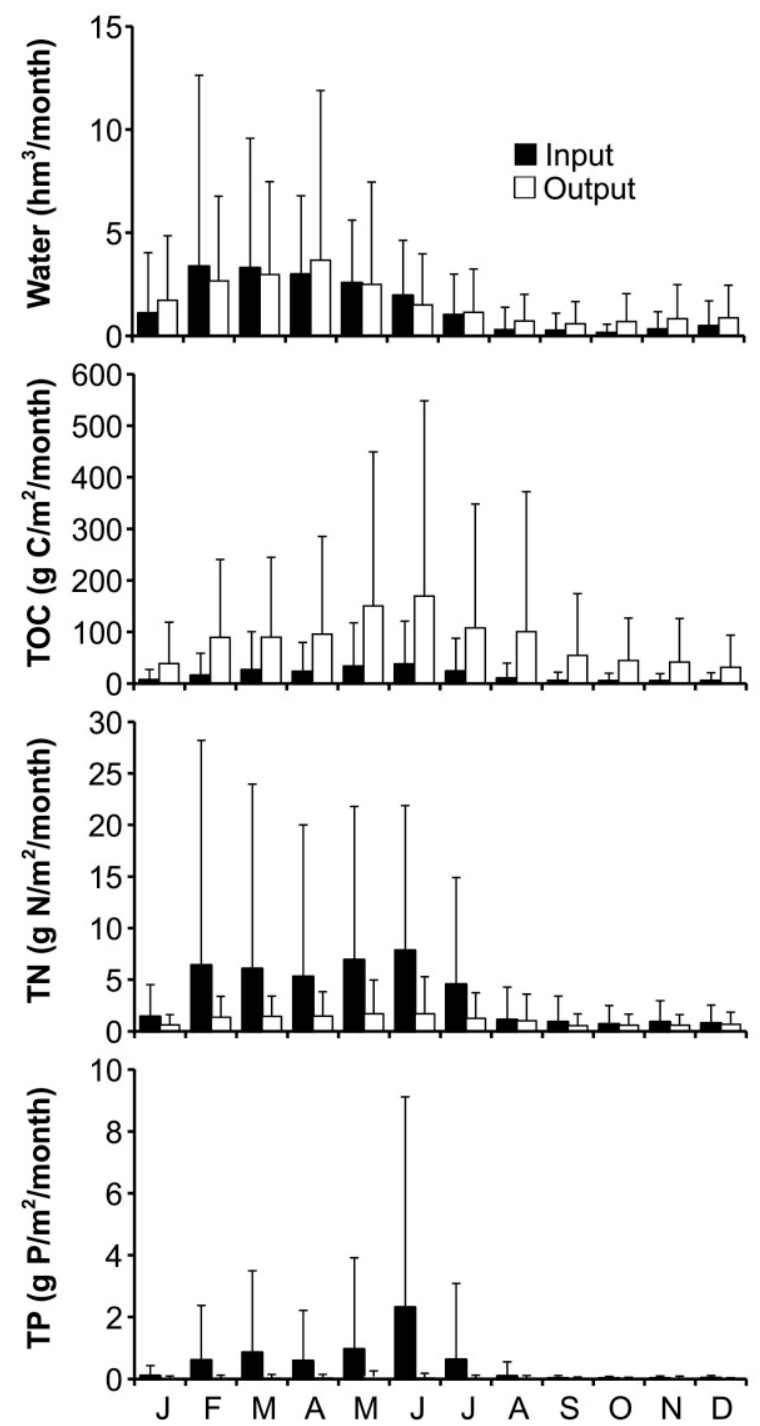

Figure 5. Annual distribution of monthly mean inputs and outputs of running water, TOC, TN and TP in the wetland for the whole period 1980-2018 (MM inputs or outputs have also been included when corresponded). Vertical bars are SD. Distribución anual de las entradas y salidas medias mensuales de agua, COT, NT y PT in el humedal para el periodo 1980-2018. Las barras verticales representan las desviaciones estándar. 

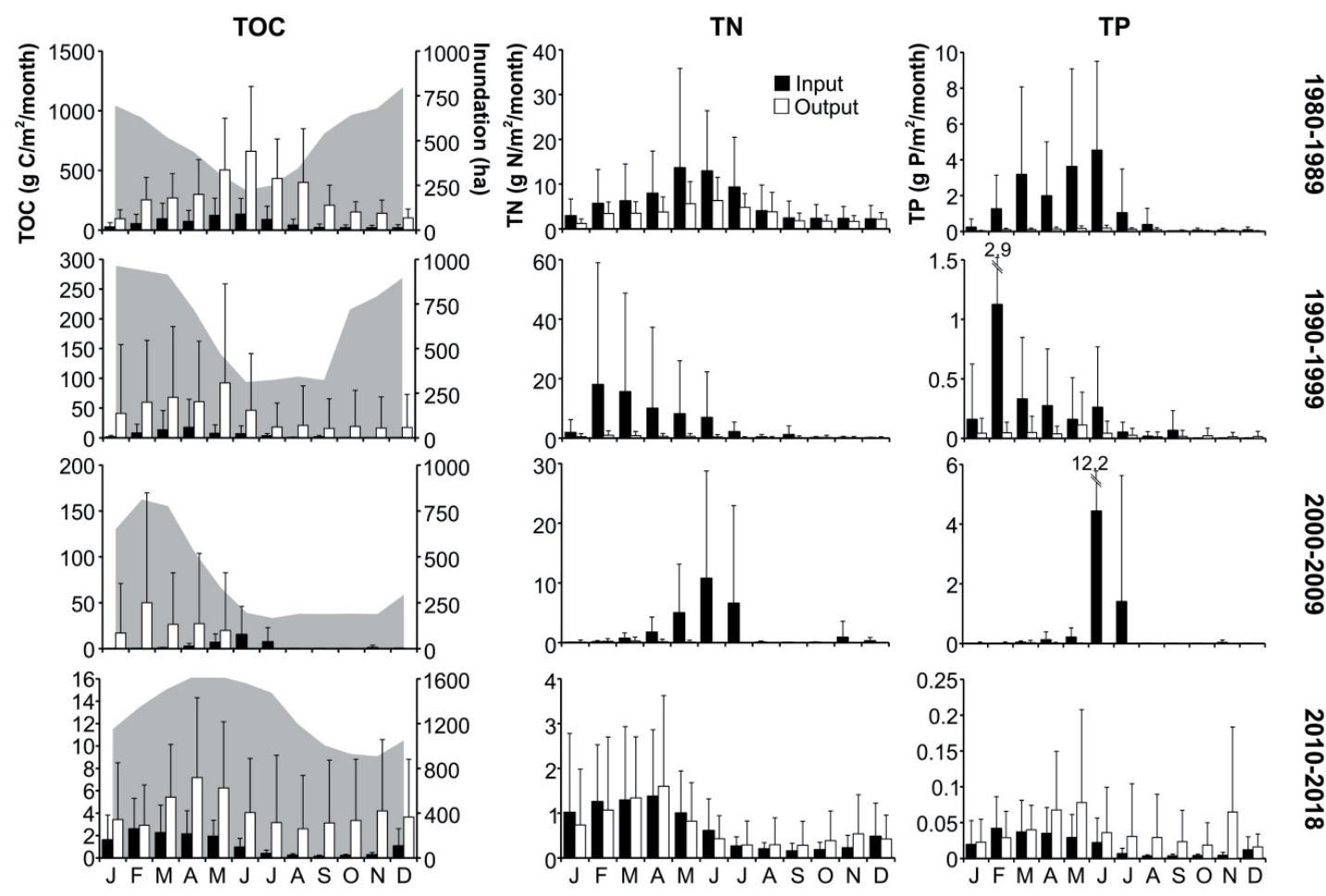

$\overrightarrow{0}$
$\stackrel{0}{0}$
$\stackrel{1}{\dot{0}}$
$\stackrel{0}{0}$
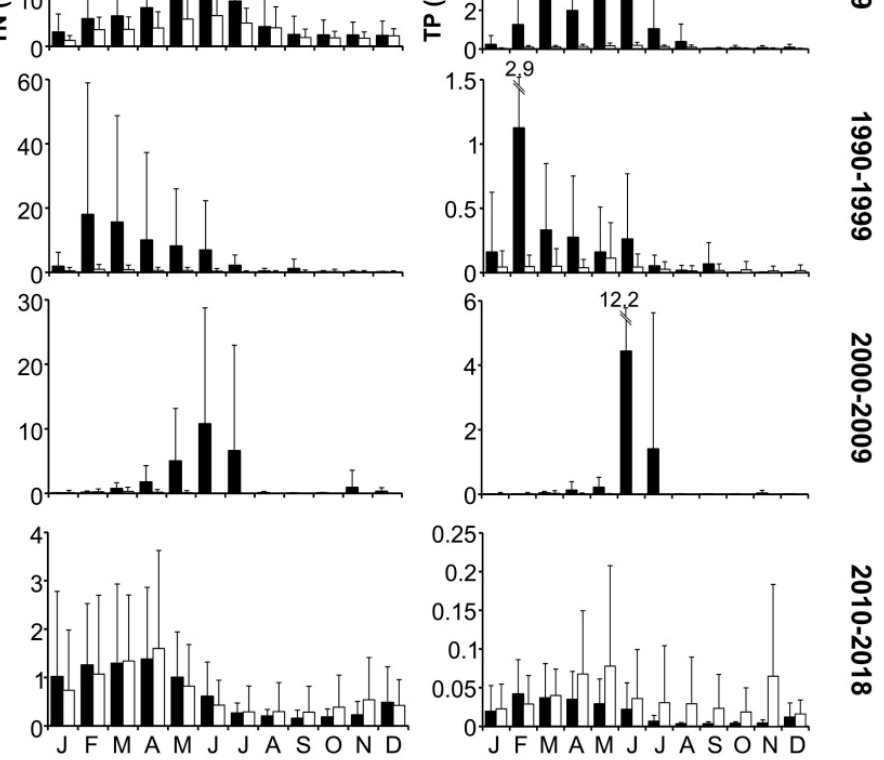

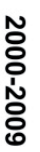

Figure 6. Changes in the mean yearly trends for input and output loadings (monthly averages) of TOC, TN and TP in TDNP for each decade between 1980 and 2018 (MM inputs or outputs have also been included when corresponded). Vertical lines represent SD. Mean inundation for each period is represented in the TOC column (grey area) to facilitate comparative visualization of its seasonal trend. Cambios en la distribución anual de las cargas de entrada y salida (medias mensuales) de COT, NTy PT en TDNP durante las décadas incluidas en este estudio (1980-2018). Las líneas verticales representan las desviaciones estándar. La inundación media de cada periodo se ha representado en la columna del COT con el sombreado gris para comparar las cargas con su tendencia temporal.

seasonal wetland inundation (or hydroperiod; Fig. 4 and 5). The source/sink character of the wetland is maintained throughout the year for all studied nutrients: wetland exported TOC consistently and acted as an efficient sink for both TN and TP (Fig. 5). In all cases, seasonal values are subject to a large interannual variability (see SD bars in Fig. 5).

Long-term series of nutrient inputs and outputs in the wetland revealed strong changes in wetland nutrient dynamics during the last 38 years, which impinged on both the magnitude and the seasonal import/export trends (Fig. 6). The initial decade, i.e. 1980-1989, considered as the closest to the unaltered wetland state, albeit not impact-free, exhibited a very different seasonal pattern for all TOC, TN and TP input/output loadings, which changed with the wetland hydroperiod (Fig. 6). Maximum input loadings of TN and TP were always changing simultaneously from 1980 s to 2010 s but not in TOC export loadings (Fig. 6). However, maximum values of all input and output loadings changed from June to April from 1980s until nowadays (Fig. 6). Input and output peaks of TOC and TP only matched seasonally in 1980-1989 but were decoupled later (Fig. 6). As cited above, the reduction in the magnitude of all the input and output loads throughout the study were remarkable, mainly in TOC (Fig. 6).

Over the years, seasonal trends for nutrient inputs and outputs and inundation matched, indicating that nutrient dynamics of the wetland are increasingly dependent on the inundation, contrary to what happened in 1980 decade (Fig. 6). In fact, the mean monthly time course of inun- 
Table 2. Pearson correlation coefficients (R) of the relationships between mean monthly (January-December, $n=12$ ) input and output loadings of TOC (g C/m²/month), TN (g N/m²/month) and TP (g P/m2/month) and the main hydrological variables. Marked correlations are significant at $p<0.05$. Coeficientes de correlación de Pearson $(R)$ de las relaciones entre las cargas medias mensuales (enero

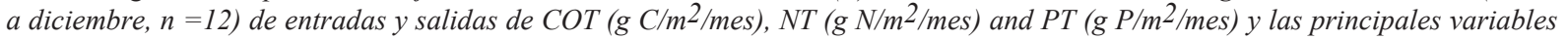
hidrológicas. Las correlaciones resaltadas son significativas para $\mathrm{p}<0.05$.

\begin{tabular}{lcccccc}
\hline & In-TOC & Out-TOC & In-TN & Out-TN & In-TP & Out-TP \\
\hline 1980-2018 & & & & & & \\
Inundation (ha) & 0.05 & -0.19 & 0.30 & 0.19 & -0.02 & 0.15 \\
Inflows $\left(\mathrm{hm}^{3} / \mathrm{yr}\right)$ & $\mathbf{0 . 6 9}$ & 0.53 & $\mathbf{0 . 8 6}$ & $\mathbf{0 . 8 1}$ & 0.55 & $\mathbf{0 . 7 5}$ \\
Outflows $\left(\mathrm{hm}^{3} /\right.$ month) & 0.57 & 0.38 & $\mathbf{0 . 7 2}$ & $\mathbf{0 . 7 0}$ & 0.37 & $\mathbf{0 . 6 9}$ \\
\hline 1980-1989 & & & & & & \\
Inundation & $\mathbf{0 . 8 0}$ & $\mathbf{- 0 . 9 4}$ & $\mathbf{- 0 . 8 2}$ & $\mathbf{- 0 . 8 8}$ & $\mathbf{- 0 . 6 5}$ & $\mathbf{- 0 . 8 8}$ \\
Inflows & $\mathbf{0 . 7 3}$ & 0.47 & $\mathbf{0 . 7 6}$ & $\mathbf{0 . 6 2}$ & $\mathbf{0 . 7 6}$ & $\mathbf{0 . 7 1}$ \\
Outflows & 0.36 & 0.18 & 0.30 & 0.33 & 0.37 & 0.39 \\
\hline 1990-1999 & & & & & & \\
Inundation & 0.17 & 0.19 & 0.33 & 0.46 & 0.37 & 0.00 \\
Inflows & $\mathbf{0 . 6 6}$ & $\mathbf{0 . 6 6}$ & $\mathbf{0 . 9 5}$ & $\mathbf{0 . 9 4}$ & $\mathbf{0 . 9 0}$ & 0.42 \\
Outflows & 0.51 & 0.53 & $\mathbf{0 . 7 8}$ & $\mathbf{0 . 8 7}$ & $\mathbf{0 . 7 9}$ & 0.29 \\
\hline 2000-2009 & & & & & & \\
Inundation & -0.32 & $\mathbf{0 . 9 0}$ & -0.33 & $\mathbf{0 . 9 3}$ & -0.31 & $\mathbf{0 . 9 3}$ \\
Inflows & $\mathbf{0 . 7 5}$ & 0.20 & $\mathbf{0 . 7 4}$ & 0.25 & 0.53 & 0.16 \\
Outflows & -0.12 & $\mathbf{0 . 6 4}$ & -0.13 & $\mathbf{0 . 6 1}$ & -0.20 & 0.54 \\
\hline 2010-2018 & & & & & & \\
Rainfall (mm/month) & $\mathbf{0 . 6 5}$ & $\mathbf{0 . 7 6}$ & $\mathbf{0 . 7 3}$ & $\mathbf{0 . 8 8}$ & $\mathbf{0 . 6 8}$ & $\mathbf{0 . 7 0}$ \\
Inundation & $\mathbf{0 . 6 2}$ & $\mathbf{0 . 6 1}$ & $\mathbf{0 . 6 5}$ & 0.55 & $\mathbf{0 . 7 0}$ & 0.49 \\
Inflows & $\mathbf{0 . 9 5}$ & $\mathbf{0 . 6 6}$ & $\mathbf{0 . 9 5}$ & $\mathbf{0 . 9 2}$ & $\mathbf{0 . 9 8}$ & 0.44 \\
Outflows & $\mathbf{0 . 8 2}$ & $\mathbf{0 . 8 9}$ & $\mathbf{0 . 8 9}$ & $\mathbf{0 . 9 1}$ & $\mathbf{0 . 8 4}$ & $\mathbf{0 . 6 5}$ \\
\hline & & & & & &
\end{tabular}

dation proved non-significant in the long-term (1980-2018) but inversely explained the nutrient budgets for the early observation period (Table 2). Later, inundation positively correlated with most nutrients in 2010-2018 (Table 2). Time-course inflow patterns matched nutrient inputs for all periods except for TP in the decade 2000-2009; TN outputs exhibited a similar seasonal inflow pattern in most decades (Table 2). Seasonality of outflows also correlated significantly with inputs and outputs of all nutrients in the last period of study (Table 2). As commented above, seasonality of inputs and outputs of TOC, TN and TP were strongly interdependent during the initial observation period (1980-1989), but this changed subsequently (Table 3 ). Correlations also indicated that seasonal inputs and outputs of TOC strongly matched the temporal dynamics of TN and TP in all periods except in 1990-1999 (Table 3). Seasonal TP output loadings were intrinsically linked with TOC outputs (Table 3 ).

\section{Long-term annual nutrient budgets}

Time courses of the annual budgets of surface water, TOC, TN and TP are summarized in Fig. 7. Again, a very large interannual variability is displayed in all studied variables. TOC and TP were exported from the wetland prodigiously during years with high precipitation, but the 
system became almost neutral in the remaining years. Contrarily, TN was imported consistently most of the time $(73 \%$ of the time the wetland was a net sink of TN). On an annual basis, during the last 38 years Las Tablas de Daimiel was a net source of TOC (467\% of TOC inputs were exported) and net sink of TN and TP (83\% of TN and $92 \%$ of phosphorus were retained and transformed in the wetland; Table 4). A significant but weak correlation was found between $\mathrm{TN}$ annual retention (TNR in \%) and TN annual external loading (TNEL in $\mathrm{g} \mathrm{N} / \mathrm{m}^{2} / \mathrm{y} ; \mathrm{TNR}=$ $\left.49.32+\ln (\mathrm{TNEL})-145.09, \mathrm{R}^{2}=0.47 p=0.002\right)$.
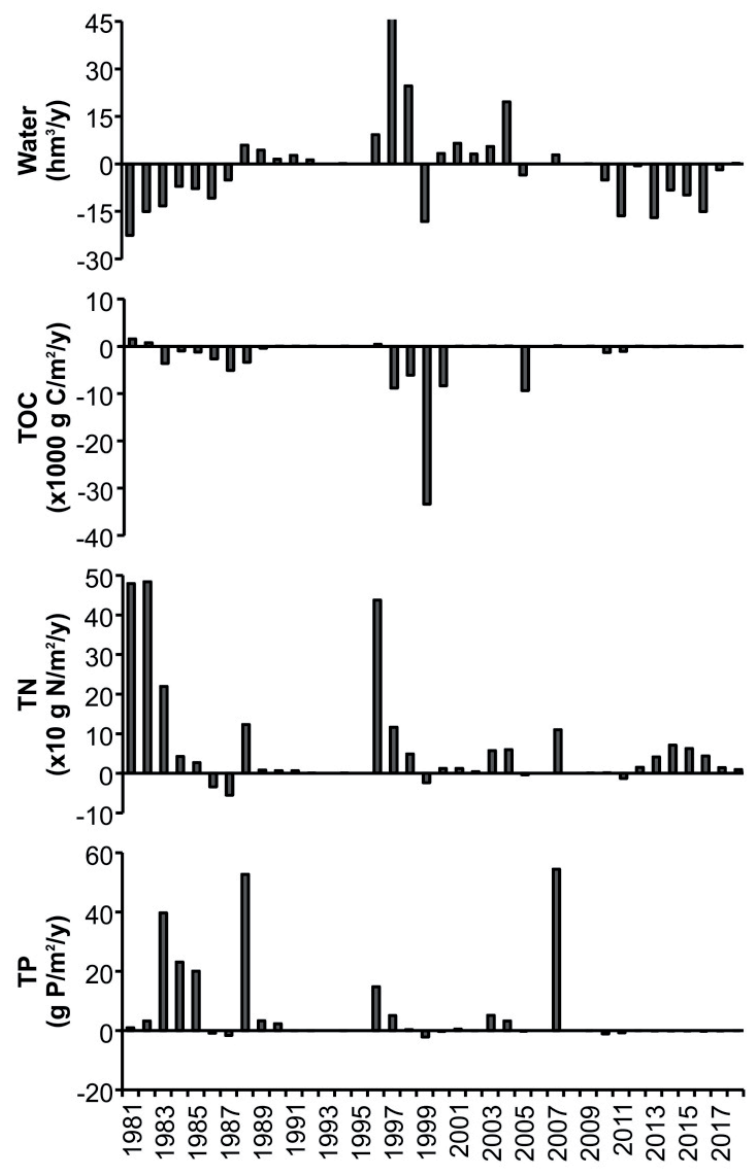

Figure 7. Time course of annual budgets of water as well as TOC, TN and TP loadings in Las Tablas de Daimiel from 1981 to 2018 (MM inputs or outputs have also been included in the budget). Evolución temporal de los balances anuales de agua y de las cargas de COT, NT y PT en Las Tablas de Daimiel de 1981 a 2018.
No significant link with TP retention could be found $(p>0.05)$.

Annual nutrient input and output budgets followed the same trend for all periods except for TP when the wetland became a budget source in the last decade (2010-2018), which also coincided with the lower phosphorus input into the system (Table 4). Throughout the study period, the wetland system extraordinarily increased TOC export from the 1980 s to 1990 s but decreased thereafter despite maintaining high TOC levels. TN import rose until the last decade, which exhibited similar rates to those of the 1980s. On a global basis, for the whole period 1980-2018 the wetland received $23111 \mathrm{t}$ of organic carbon, $5740 \mathrm{t}$ of nitrogen and $490 \mathrm{t}$ of phosphorus; in the same period, the wetland system exported 148741 t of organic carbon, and stored, and transformed $2808 \mathrm{t}$ of nitrogen and $345 \mathrm{t}$ of phosphorus. However, long-term data on nutrient budgets in Las Tablas show that sources are decreasing and TN and TP sinks are changing: in the decade 1980-1989 the total exported TOC was $69982 \mathrm{t} \mathrm{C}$, and the combined amounts of imported TN and TP were 848 and $292 \mathrm{t} \mathrm{N}$ and $\mathrm{P}$, respectively. In the last decade (2010-2018) the total amount of exported TOC was only $4844 \mathrm{t} \mathrm{C}$, and the wetland became a source of TN and TP (the net budgets indicated exports of TN of $90 \mathrm{t}$ and of TP of $33 \mathrm{t}$ ).

\section{DISCUSSION}

Our results highlight the complex and erratic interactions taking place in Las Tablas de Daimiel during the last 38 years. Hydrology has been considered as the main driver of this ecosystem, with changes associated to groundwater overexploitation altering the ecosystem structure and function (Cirujano et al., 2010). Changes in biodiversity and food webs have previously been assessed (Álvarez-Cobelas et al., 2001; Álvarez-Cobelas et al., 2010); however, the scope of the functional changes has yet to be evaluated. The large annual variation in the hydrology observed after the 1980s in Las Tablas is similar to that in other semi-arid lakes (Coppens et al., 2016). In semi-arid areas, water resources are highly exploited and river flows often exhibit an 
unpredictable and non-seasonal pattern. tion has also been cited to play a key role in this Long-term data on TDNP inundation show that the seasonal time-course did not depend exclusively on inflows and outflows. Evapotranspirawetland, controlling water balance in the short-term (Sánchez-Carrillo et al., 2004) but data are not available to test its effect in the

Table 3. Relationships (Pearson correlation coefficients) between average seasonal input and output loadings ( $\mathrm{n}=12$, monthly average for each period) of TOC ( $\mathrm{g} \mathrm{C} / \mathrm{m}^{2} /$ month), TN (g N/m²/month) and TP $\left(\mathrm{g} \mathrm{P} / \mathrm{m}^{2} / \mathrm{month}\right)$ in Las Tablas de Daimiel for each decade between 1980 and 2018. Marked correlations are significant at $p<0.05$. Coeficientes de correlación de Pearson, entre las cargas promedio mensuales de entradas y salidas $\left(n=12\right.$, promedio mensual para cada periodo) de COT $\left(\mathrm{g} \mathrm{C} / \mathrm{m}^{2} / \mathrm{mes}\right), \mathrm{NT}\left(\mathrm{g} N / \mathrm{m}^{2} / \mathrm{-}\right.$ mes) y PT (g P/m $2 / m e s)$ en Las Tablas de Daimiel para todo el periodo de estudio y por década. Las correlaciones resaltadas son significativas para $\mathrm{p}<0.05$.

\begin{tabular}{lccccc}
\hline & In-TOC & Out-TOC & In-TN & Out-TN & In-TP \\
\hline $\mathbf{1 9 8 0 - 2 0 1 8}$ & & & & & \\
Out-TOC & $\mathbf{0 . 9 2}$ & & & & \\
In-TN & $\mathbf{0 . 9 3}$ & $\mathbf{0 . 8 4}$ & & & \\
Out-TN & $\mathbf{0 . 9 5}$ & $\mathbf{0 . 9 1}$ & $\mathbf{0 . 9 6}$ & & \\
In-TP & $\mathbf{0 . 9 0}$ & $\mathbf{0 . 8 6}$ & $\mathbf{0 . 8 6}$ & $\mathbf{0 . 8 2}$ & \\
Out-TP & $\mathbf{0 . 9 2}$ & $\mathbf{0 . 8 8}$ & $\mathbf{0 . 8 9}$ & $\mathbf{0 . 9 3}$ & 0.74 \\
\hline $\mathbf{1 9 8 0 - 8 9}$ & & & & & \\
Out-TOC & $\mathbf{0 . 8 8}$ & & & & \\
In-TN & $\mathbf{0 . 9 7}$ & $\mathbf{0 . 8 9}$ & & & \\
Out-TN & $\mathbf{0 . 9 3}$ & $\mathbf{0 . 9 6}$ & $\mathbf{0 . 9 4}$ & & \\
In-TP & $\mathbf{0 . 9 5}$ & $\mathbf{0 . 7 9}$ & $\mathbf{0 . 8 9}$ & $\mathbf{0 . 8 4}$ & \\
Out-TP & $\mathbf{0 . 9 5}$ & $\mathbf{0 . 9 5}$ & $\mathbf{0 . 9 6}$ & $\mathbf{0 . 9 7}$ & $\mathbf{0 . 8 9}$ \\
\hline 1990-99 & & & & & \\
Out-TOC & $\mathbf{0 . 7 5}$ & & & & \\
In-TN & $\mathbf{0 . 8 0}$ & $\mathbf{0 . 7 8}$ & & & \\
Out-TN & $\mathbf{0 . 7 4}$ & $\mathbf{0 . 8 3}$ & $\mathbf{0 . 9 5}$ & & \\
In-TP & 0.47 & 0.51 & $\mathbf{0 . 8 5}$ & $\mathbf{0 . 8 3}$ & \\
Out-TP & 0.46 & $\mathbf{0 . 9 1}$ & 0.53 & $\mathbf{0 . 6 1}$ & 0.31 \\
\hline 2000-2009 & & & & & \\
Out-TOC & -0.21 & & & & \\
In-TN & $\mathbf{0 . 9 9}$ & -0.22 & & & \\
Out-TN & -0.23 & $\mathbf{0 . 8 8}$ & -0.23 & & \\
In-TP & $\mathbf{0 . 9 3}$ & -0.28 & $\mathbf{0 . 9 1}$ & -0.28 & \\
Out-TP & -0.26 & $\mathbf{0 . 7 9}$ & -0.26 & $\mathbf{0 . 9 8}$ & \\
\hline $\mathbf{2 0 1 0 - 1 8}$ & & & & & \\
Out-TOC & 0.55 & & & & \\
In-TN & $\mathbf{0 . 9 8}$ & $\mathbf{0 . 6 3}$ & & & \\
Out-TN & 0.86 & 0.74 & 0.92 & & \\
In-TP & $\mathbf{0 . 9 8}$ & 0.57 & $\mathbf{0 . 9 6}$ & $\mathbf{0 . 8 7}$ & \\
Out-TP & 0.32 & $\mathbf{0 . 8 0}$ & 0.37 & 0.50 & \\
\hline & & & & & \\
\hline
\end{tabular}


long-term. Recently, the overdrafted hydrology of La Mancha Humeda district underwent a surprising recovery due to a prolonged period with high precipitation (2010-2016), and the aquifer again discharged groundwater to the wetland as of 2012 via the Guadiana River (Martínez-Alfaro et al., 2018). This anomalous wet period has changed the hydrologic functioning of the wetland during the last 30 years, approximating the system existing prior to aquifer overexploitation. This provides a good opportunity to compare the nutrient dynamics in both periods in order to check how the effects of long-term hydrological degradation and eutrophication have affected nutrient processes and hence wetland functionality.

Considering the whole observation period, Las Tablas de Daimiel can be considered as an extraordinary source of TOC and a large sink for $\mathrm{TN}$ and TP. This result concurs with those of Johnston (2001) and Fisher \& Acreman (2004). However, these nutrient dynamics in the wetland have changed substantially since the 1980s. Large variability in time-course nutrient concentration at the inlet and outlet sites has been reported in this wetland, as well as in another semi-arid shallow water bodies (Sánchez-Carrillo et al., 2010; McJannet et al., 2012; Coppens et al., 2016). Most changes in nutrient concentration in aquatic systems are influenced to a large extent by changes in external loading (Søndergaard, 2007). In TDNP, the depletion in TP concentration at the inlet $(\mathrm{PG})$ is a clear example of the effects of improvements in wastewater treatment in the Upper Guadiana basin, a trend well known in

Table 4. Annual budgets of water and nutrients (TOC, TN and TP) in Las Tablas de Daimiel wetland for the period 1980-2018 and for each of the decades included in the study. Total is the sum of the annual inputs or outputs for the entire period considered. Budget is the mean annual loading. Ret/Exp are retention or export as a percentage of the mean annual inputs. Positive budget indicates retention and negative exportation (sink and source, respectively) of water and nutrients. Balances anuales de agua y nutrientes (COT, NT y PT) en Las Tablas de Daimiel para el periodo completo (1980-2018) y separado por décadas. El total es la suma anual de las entradas y de las salidas para el periodo en cuestión. "Budget" representa la carga media anual. Ret/Exp son la retención o exportación expresadas como el porcentaje de las entradas medias anuales. Un balance positivo indica retención y uno negativo exportación (sumidero y fuente, respectivamente) de agua y nutrientes.

\begin{tabular}{|c|c|c|c|c|c|c|c|c|c|}
\hline & & \multicolumn{2}{|c|}{ Water $\left(\mathrm{hm}^{3} / \mathrm{yr}\right)$} & \multicolumn{2}{|c|}{$\operatorname{TOC}\left(\mathrm{g} \mathrm{C} / \mathrm{m}^{2} / \mathrm{yr}\right)$} & \multicolumn{2}{|c|}{$\mathrm{TN}\left(\mathrm{g} \mathrm{N} / \mathrm{m}^{2} / \mathrm{yr}\right)$} & \multicolumn{2}{|c|}{$\mathrm{TP}\left(\mathrm{g} \mathrm{P} / \mathrm{m}^{2} / \mathrm{yr}\right)$} \\
\hline & & Input & Output & Input & Output & Input & Output & Input & Output \\
\hline \multirow{4}{*}{ 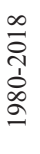 } & Average & $7.1 \pm 10.6$ & $8.1 \pm 10.5$ & $466.6 \pm 1342.6$ & $2643.9 \pm 5860.2$ & $75.6 \pm 139.4$ & $12.8 \pm 19.5$ & $6.2 \pm 13.8$ & $0.5 \pm 0.7$ \\
\hline & Total & 267.9 & 306.6 & 17730.4 & 100469.7 & 2873.0 & 486.5 & 235.8 & 19.0 \\
\hline & Budget & & -1.0 & & -2177.4 & & 62.8 & & 5.7 \\
\hline & Ret/Exp & & -14 & & -467 & & 83 & & 92 \\
\hline \multirow{4}{*}{$\begin{array}{l}\text { के } \\
\text { 1े } \\
\& \\
\stackrel{2}{=}\end{array}$} & Average & $4.3 \pm 3.9$ & $12.2 \pm 8.1$ & $1841.8 \pm 2,351.0$ & $3514.8 \pm 2045.2$ & $183.7 \pm 219.2$ & $39.8 \pm 22.1$ & $16.4 \pm 19.4$ & $1.1 \pm 0.6$ \\
\hline & Total & 38.3 & 109.7 & 16576.6 & 31633.0 & 1652.9 & 358.0 & 147.3 & 9.8 \\
\hline & Budget & & -7.1 & & -1505.6 & & 129.5 & & 13.8 \\
\hline & $\operatorname{Ret} / \operatorname{Exp}$ & & -168 & & -82 & & 71 & & 84 \\
\hline \multirow{4}{*}{$\begin{array}{l}\text { જे } \\
\text { ఏे } \\
\text { ळ }\end{array}$} & Average & $10.6 \pm 17.4$ & $3.6 \pm 6.1$ & $56.6 \pm 127.3$ & $4842.1 \pm 10519.3$ & $64.0 \pm 137.7$ & $4.6 \pm 8.3$ & $2.4 \pm 4.7$ & $0.4 \pm 0.8$ \\
\hline & Total & 105.7 & 36.5 & 566.3 & 48421.2 & 639.7 & 45.7 & 24.3 & 4.3 \\
\hline & Budget & & 6.9 & & -4785.5 & & 59.4 & & 2.0 \\
\hline & $\operatorname{Ret} / \operatorname{Exp}$ & & 65 & & -8451 & & 93 & & 82 \\
\hline \multirow{4}{*}{$\begin{array}{l}\text { oे } \\
\text { o } \\
\text { } \\
\text { ㄱ. }\end{array}$} & Average & $4.4 \pm 5.8$ & $0.7 \pm 1.6$ & $33.7 \pm 49.3$ & $1776.5 \pm 3751.9$ & $26.1 \pm 37.3$ & $0.9 \pm 1.9$ & $6.2 \pm 16.6$ & $0.07 \pm 0.17$ \\
\hline & Total & 44.0 & 6.7 & 337.3 & 17764.7 & 261.4 & 8.9 & 62.3 & 0.73 \\
\hline & Budget & & 3.7 & & -1742.7 & & 25.2 & & 6.2 \\
\hline & $\operatorname{Ret} / \operatorname{Exp}$ & & 85 & & -5167 & & 97 & & 99 \\
\hline \multirow{4}{*}{$\begin{array}{l}\ddot{\infty} \\
\stackrel{0}{0} \\
\stackrel{0}{\sigma}\end{array}$} & Average & $8.9 \pm 9.2$ & $17.1 \pm 13.9$ & $27.8 \pm 18.8$ & $294.5 \pm 532.9$ & $35.4 \pm 26.3$ & $8.2 \pm 9.0$ & $0.2 \pm 0.2$ & $0.46 \pm 0.56$ \\
\hline & Total & 79.9 & 153.8 & 250.3 & 2650.8 & 319.0 & 73.9 & 1.9 & 4.11 \\
\hline & Budget & & -7.4 & & -240.1 & & 24.5 & & -0.2 \\
\hline & $\operatorname{Ret} / \operatorname{Exp}$ & & -83 & & -863 & & 69 & & -102 \\
\hline
\end{tabular}


other European countries (Tudesque et al., 2008). However, for $20 \%$ of the months recorded, the TP concentration exceeded the limits set by EU regulation for inputs to a National Park (Directive 91/271). DOC concentrations in the inflows have dropped in Las Tablas (over $90 \%$ of TOC is DOC; Álvarez-Cobelas et al., 2010) in the long-term, contrary to the observed pattern in most temperate water bodies (Evans et al., 2005). The cited improvement in wastewater treatment may also be responsible for the downward trend in TOC observed in the inflowing waters, which would imply that most of the carbon reaching the wetland came from wastewaters. Long-term DOC decline in large rivers is primarily related with a reduction in wetland and riparian areas within the watersheds (Duan et al., 2017), which is also evident in the Gigüela catchment albeit unquantified. When analyzing the complete time series, we can observe a strong nutrient dilution effect which decreased TOC concentration during high-discharge periods, becoming more evident during the last wet period (2010-2018), as also observed by Arreghini et al. (2005) in an Argentinian stream. Flat terrain surrounding TDNP and the Gigüela watershed rarely generates runoff during storms and most water flow comes from head streams. On the time scale of our observations (monthly), our results probably only catch point-source effects in nutrient dynamics but diffuse sources would be comparatively unimportant.

DOC exportation is a usual feature of wetlands (Laudon et al., 2004; Cai et al., 2016, Joung et al., 2019), likely due to decomposition of plant detritus and DOC production, which match seasonality of TOC output loads in Las Tablas (Fig. 4). However, the mean export rates at monthly and annual scales measured in Las Tablas exceed those cited in other studies (e.g. Fisher \& Acreman, 2004; Joung et al., 2019). We do not know the main reasons for this tremendous disparity, but we should probably look at wetland functioning, which is causing a short circuit in some biogeochemical processes in periods when the outflow is disrupted, to expand wetland inundation for longer. In the 1980s the annual ratio between output and input was 1.3 while in the next two decades it increased to 85 and 53 . During the 2010-2018 decade TOC exportation decreased considerably but the ratio output:input remained high (10.3). Also, the seasonality of TOC export changed with maximum loadings occurring before the growing season had started. Despite the long time series, making predictions for a wetland system like Las Tablas is risky, and it is difficult to forecast trends in TOC export for the next decade. However, since stream denitrification is linked to DOC availability (Van Cleemput et al., 2007) we must be alerted to an extreme reduction in DOC export because it would impact the capacity of the Guadiana River downstream of Las Tablas to effectively remove nitrogen.

When considering this long period, $\mathrm{TN}$ and TP retention percentages in the wetland are similar to those cited in our previous study on nutrient dynamics for the period 1996-1999 (SánchezCarrillo \& Álvarez-Cobelas, 2001), not including macrophyte leaching and internal loading as additional nutrient sources, which can be very noticeable in this wetland (Sánchez-Carrillo \& Álvarez-Cobelas, 2001). Retentions are higher than those cited in other wetlands, even if input loadings were higher (Saunders \& Kalff, 2001; Mitsch et al., 2005; Day et al., 2006). TN and TP retentions in TDNP are similar to those reported for treatment wetlands (e.g. Comín et al., 1997; Jahangir et al., 2016). Whilst wetland capacity of TOC export seems consistent in the long term, both TN and TP retentions demonstrate the onset of exhaustion symptoms. For the entire period, TP retention clearly falls as does the inflow in this wetland (Sánchez-Carrillo \& Álvarez-Cobelas, 2001), contrary to early findings on phosphorus dynamics in wetlands (i.e. Marion \& Brient, 1998), but in the recent 2010-2018 wet period, the wetland was a source of phosphorus $50 \%$ of the time. Efficient nitrogen retention in wetlands is associated with uptake and retention by macrophytes, but mainly with high denitrification efficiency (Sanders \& Kalff, 2001; Van Cleemput et al., 2007) and a decline in TN retention should be explained by changes in these mechanisms. On the other hand, once biotic processes consume the available inorganic $\mathrm{P}$, the phosphorus retention capacity in wetlands depends on $\mathrm{P}$ sorption dynamics in soils, which can release phosphorus when the buffer capacity is achieved and the TP concentration in the water column is lower than in 
soil pore waters (Reddy \& DeLaune, 2008). Elevated nitrogen and phosphorus contents measured in TDNP sediments, which are higher than reported in other impacted wetlands (Álvarez-Cobelas et al., 2010), could confirm this hypothesis. Current data do not enable us to conclude whether the wetland has reached saturation in TN and TP (i.e. the maximum nutrient retention capacity), nor identify the main causes; however, results on nutrient budgets indicate that it is approximating that scenario.

Seasonal patterns in TOC, TN and TP have changed greatly in Las Tablas during the last 3 decades. If we evaluate the changes by comparing them to the oldest period, we cannot define any clear trend. Although the last period would appear to approximate the initial (more pristine) state, there are still important differences, as yet unevaluated. For example, the highest inputs of TOC, TN and TP occur in winter, before the growing cycle when they are not processed by bacteria, fungi and plants due to the low metabolic activity. It might likely be another cause of increased exports, and probably this fact is also a partial cause of the decoupling observed in TOC and TP inputs and outputs. Several processes were inversely dependent on seasonal inundation in 1980s but this is no longer the case. Currently, flow patterns dictate the nutrient dynamics in the wetland except in TP, whose seasonality is not linked so closely to hydrology. Relationships exhibited by the seasonal inputs and outputs of all nutrients during the 1980s demonstrate the intrinsic relationships among all biogeochemical processes occurring in the wetland which subsequently disappeared, at least partially. Relationships between TOC, TN and TP inputs followed the same patterns throughout the study, but other relationships were lost, which again indicates the decoupling of many processes in the wetland.

Wetlands are complex ecosystems, which are exposed to several impacts including climate change, hydrological overexploitation, point and diffuse pollution, land reclamation and desiccation, which operate at different temporal and spatial scales. Responding to these factors, biogeochemical processes are constantly changing in order to adapt to new conditions but the response time of each process is different, as is the spatial scale of change. Long-term studies of wetland nutrient dynamics are unusual and more studies are needed to discover how nutrient processes are changing with the wetland transformation. Such information will enable us to assess which transformations are affected most and to evaluate how these changes are sustained over time. Our study demonstrates Las Tablas de Daimiel, an impacted but surviving wetland, has changed to adapt to several point and sustained impacts and now has become a different ecosystem, exposed to new biogeochemical conditions. While hydrology in the wetland is becoming more favorable to lasting wetland inundation, other ecological and biogeochemical processes, such as carbon export and $\mathrm{N}$ and $\mathrm{P}$ retention are beginning to show symptoms of exhaustion.

During the last 38 years the wetland has undergone similar environmental scenarios several times (drought, high water level, high and low organic external load, toxic organic compounds, etc.) but the biogeochemical response of the system has never been repeated. The time scale of environmental interactions in ecosystems caused by human activity is still unpredictable. Therefore, long-term observations of ecosystems are fundamental to understanding how nature will respond to future global change.

\section{ACKNOWLEDGEMENTS}

Several projects funded by the Agency for National Parks from 1992 supported this study. The TDNP staff, especially Carlos Ruiz de la Hermosa, Manuel Carrasco, María Jesús Sánchez Soler and Alfonso Díaz Cambronero supplied data and provided logistic and financial support for field campaigns. We also thank the technical support provided by José Luis Ayala, Angel Rubio, María José Ortíz, Eva Delgado and Palmira Riolobos during all these years. This is a scientific contribution of the LTERSpain site "Las Tablas de Daimiel".

\section{REFERENCES}

APHA. 2005. Standard Methods for the Examination of Water and Wastewater, American Public Health Association, Washington DC, United States of America. 
ÁLVAREZ-COBELAS, M. \& S. CIRUJANO (eds.). 1996. Las Tablas de Daimiel, ecología acuática y sociedad. Ministerio de Medio Ambiente, Madrid, Spain.

ÁlVAREZ-COBELAS, M. \& S. CIRUJANO. 2007. Multilevel responses of emergent vegetation to environmental factors in a semiarid floodplain. Aquatic Botany, 87: 49-60.

ÁLVAREZ-COBELAS, M., S. SÁNCHEZCARRILLO, S. CIRUJANO \& D. G. ANGELER. 2010. A Story of the wetland water quality deterioration, salinization, pollution, eutrophication and siltation. In, S. SÁNCHEZCARRILLO \& D.G. ANGELER (eds.), Ecology of Threatened Semi-Arid Wetlands, Long-term research in Las Tablas de Daimiel. Series Wetlands, Ecology, Conservation and Management, Volume 2. Springer, Dordrecht, The Netherlands. pp, 109-133.

ARREGHINI, S., L. DE CABO, R. SEOANE, N. TOMAZIN, R. SERAFINI \& A. F. DE LORIO. 2005. Influence of rainfall on the discharge, nutrient concentrations and loads of a stream of the "Pampa Ondulada" (Buenos Aires, Argentina). Limnetica, 24: 225-236.

BACHMANN, R. W. \& D. E. CANFIELD. 1996. Use of an alternative method for monitoring total nitrogen concentrations in Florida lakes. Hydrobiologia, 323: 1-8.

BHOMIA, R. K. \& K. R. REDDY. 2018. Influence of vegetation on long-term phosphorus sequestration in subtropical treatment wetlands. Journal of Environmental Quality, 47: 361-370.

CAI, Y., M-J. SHIM, L. GUO \& A. SHILLER. 2016. Floodplain influence on carbon speciation and fluxes from the lower Pearl River, Mississippi. Geochimica et Cosmochimica Acta, 186: 189-206.

CARVALHO, L. \& A. KIRIKA. 2003. Changes in shallow lake functioning, response to climate change and nutrient reduction. Hydrobiologia, 506: 789-796.

CIRUJANO, S., M. ÁLVAREZ-COBELAS \& R. SÁNCHEZ-ANDRÉS. 2010. Macrophyte ecology and its long-term dynamics. In, S. SÁNCHEZ-CARRILLO \& D.G. ANGELER (eds.), Ecology of Threatened Semi-Arid Wetlands, Long-term research in Las Tablas de Daimiel. Series Wetlands, Ecology, Conservation and Management, Volume 2. Springer, Dordrecht, The Netherlands. pp, 175-195.

COMÍN, F. A., J. A. ROMERO, V. ASTORGA \& C. GARCÍA. 1997. Nitrogen removal and cycling in restores wetlands used as filters of nutrients for agricultural runoff. Water Science and Technology, 35: 255-261.

COPPENS, J., A. ÖZEN, Ü.N. TAVŞANOĞLU, Ş. ERDOĞAN, E. E. LEVI, C. YOZGATLIGIL, E. JEPPESEN \& M. BEKLIOĞLU. 2016. Impact of alternating wet and dry periods on long-term seasonal phosphorus and nitrogen budgets of two shallow Mediterranean lakes. Science of the Total Environment, 563-564: 456-467.

DAY, J. W., A. WESTPHAL, R. PRATT, E. HYFIELD, J. RYBCZYK, G. P. KEMP, J. N. DAY \& B. MARX. 2006. Effects of long-term municipal effluent discharge on the nutrient dynamics, productivity, and benthic community structure of a tidal freshwater forested wetland in Louisiana. Ecological Engineering, 27: 242-257.

DUAN, S., Y. HE, S. S. KAUSHAL, T. S. BIANCHI, N. D. WARD \& L. GUO. 2017. Impact of Wetland decline on decreasing dissolved organic carbon concentrations along the Mississippi River Continuum. Frontiers in Marine Science, 3: 280.

EVANS, C. D., D. T. MONTEITH \& D. M. COOPER. 2005. Long-term increases in surface water dissolved organic carbon, observations, possible causes and environmental impacts. Environmental Pollution, 137: $55 \mathrm{e} 71$.

FISHER, J. \& M. C. ACREMAN. 2004. Wetland nutrient removal, a review of the evidence. Hydrology and Earth System Sciences, 8: 673-685.

GERSON, J. R., C. T. DRISCOLL \& K. M. ROY. 2016. Patterns of nutrient dynamics in Adirondack lakes recovering from acid deposition. Ecological Applications, 26: 1758-1770.

HEATHWAITE, A. L. 2010. Multiple stressors on water availability at global to catchment scales, understanding human impact on nutrient cycles to protect water quality and water 
availability in the long term. Freshwater Biology, 55: 241-257.

HOBBIE, J. E., S. R. CARPENTER, G. N. B. RIMM, J. R. GOSZ \& T. R. SEASTEDT. 2003. The US Long Term Ecological Research Program. BioScience, 53: 21-32.

INYPSA. 1990. Estudio de seguimiento de los resultados del Plan de Regeneración Hídrica del Parque Nacional Las Tablas de Daimiel. Final Report, Madrid, Spain.

JAHANGIR, M. M. R., K. G. RICHARDS, M. G. HEALY, L. GILL, C. MÜLLER, P. JOHNSTON \& O. FENTON. 2016. Carbon and nitrogen dynamics and greenhouse gas emissions in constructed wetlands treating wastewater, a review. Hydrology and Earth System Sciences, 20: 109-123.

JOHNSTON, C. A. 1991. Sediment and nutrient retention by freshwater wetlands, effects on surface water quality. Critical Reviews in Environmental Control, 21: 491-565.

JOUNG, D., L. GUO \& A. M. SHILLER. 2019. Role of the Atchafalaya River Basin in regulating export fluxes of dissolved organic carbon, nutrients, and trace elements to the Louisiana Shelf. Journal of Hydrology. DOI: 10.1016/j.hydroa.2019.100018

KADLEC, R. H. \& R. L. KNIGHT. 1996. Treatment Wetlands, CRC Press, New York, United States of America.

LAUDON, H., S. KÖHLER \& I. BUFFAM. 2004. Seasonal TOC export from seven boreal catchments in northern Sweden. Aquatic Sciences, 66: 223-230.

LIKENS, G. E., F. H. BORMANN, N. M. JOHNSON, D. W. FISHER \& R. S. PIERCE. 1970. Effects of forest cutting and herbicide treatment on nutrient budgets in the Hubbard Brook watershed-ecosystem. Ecological Monographics, 40: 23-47.

MARION, L. \& L. BRIENT. 1998. Wetland effects on water quality, input-output studies of suspended particulate matter, nitrogen (N) and phosphorus (P) in Grand-Lieu, a natural plain lake. Hydrobiologia, 373/374: 217-235.

MARTÍNEZ-SANTOS, P. E., S. CASTAÑOCASTAÑO \& A. HERNÁNDEZ-ESPRIÚ. 2018. Revisiting groundwater overdraft based on the experience of the Mancha Occidental
Aquifer, Spain. Hydrogeology Journal, 26: 1083-1097.

MCJANNET, D., J. WALLACE, R. KEEN, A. HAWDON \& J. KEMEI. 2012. The filtering capacity of a tropical riverine wetland, II. Sediment and nutrient balances. Hydrological Processes, 26: 53-72.

MITSCH, W. J., J. W. DAY, L. ZHANG \& R. R. LANE. 2005. Nitrate-nitrogen retention in wetlands in the Mississippi River Basin. Ecological Engineering, 24: 267-278.

MITSCH, W. J. \& J. G. GOSSELINK. 2007. Wetlands. 4th Edition. Wiley, New York, United States of America.

MULHOLLAND, P. J. \& J. R. WEBSTER. 2010. Nutrient dynamics in streams and the role of J-NABS. Freshwater Science, 29: 100-117.

PELSTER, D., J.M. BURKE, K. COULING, S. H. LUKE, D. W. SMITH \& E. E. PREPAS. 2008. Water and nutrient inputs, outputs, and storage in Canadian boreal forest wetlands, a review. Journal of Environmental Engineering and Science, 7: 35-50

REDDY, K. R. \& R. D. DELAUNE. 2008. Biogeochemistry of Wetlands, Science and Applications. CRC Press, Boca-Raton, United States of America.

SÁEZ-ROYUELA, R. 1977. Contribución al estudio ecológico de Las Tablas de Daimiel. III. Las aguas. Anales INIA, 3: 101-149.

SÁNCHEZ-CARRILLO, S. \& M. ÁLVAREZ-COBELAS. 2001. Nutrient dynamics and eutrophication patterns in a semiarid wetland, the effects of fluctuating hydrology. Water Air Soil Pollution, 131: 97-118.

SÁNCHEZ-CARRILLO, S., D. G. ANGELER, R. ÁNCHEZ ANDRÉS, M. ÁLVAREZ COBELAS \& J. GARATUZA-PAYÁN. 2004. Evapotranspiration in wetlands, relationships between inundation and the macrophyte cover, open water ratio. Advances in Water Resources, 27: 643-655.

SÁNCHEZ-CARRILLO, S. \& M. ÁLVAREZ-COBELAS. 2010. Climate and hydrologic trends, climate change versus hydrologic overexploitation as determinants of the fluctuating wetland hydrology. In, S. SÁNCHEZCARRILLO \& D.G. ANGELER (eds.), Ecology of Threatened Semi-Arid Wetlands, 
Long-term research in Las Tablas de Daimiel. Series Wetlands, Ecology, Conservation and Management, Volume 2. Springer, Dordrecht, The Netherlands. pp, 45-84.

SÁNCHEZ-CARRILLO, S. \& D. G. ANGELER (eds.). 2010. Ecology of Threatened Semi-Arid Wetlands, Long-term research in Las Tablas de Daimiel. Series Wetlands, Ecology, Conservation and Management, Volume 2. Springer, Dordrecht, The Netherlands.

SÁNCHEZ-CARRILLO, S., D.G. ANGELER, S. CIRUJANO \& M. ÁLVAREZ-COBELAS. 2010. The wetland, its catchment settings and socioeconomic relevance, an overview. In, S. SÁNCHEZ-CARRILLO \& D. G. ANGELER (eds.), Ecology of Threatened Semi-Arid Wetlands, Long-term research in Las Tablas de Daimiel. Series Wetlands, Ecology, Conservation and Management, Volume 2. Springer, Dordrecht, The Netherlands. pp, 3-20.

SAUNDERS, D. L. \& J. KALFF. 2001. Nitrogen retention in wetlands, lakes and rivers. Hydrobiologia, 443: 205-212.

SØNDERGAARD, M. 2007. Nutrient dynamics in lakes with emphasis on phosphorus, sediment and lake restoration. $\mathrm{PhD}$ thesis, University of Aarus, Denmark. (https://www2. dmu.dk/pub/dsc_ms_uk.pdf)

TUDESQUE, L., M. GEVRAY, G. GRENOUILLET \& S. LEK. 2008. Long-term changes in water physicochemistry in the Adour-Garonne hydrographic network during the last three decades. Water Research, 42: 732-742.

VAN CLEEMPUT, O., P. BOECKX, P-E. LINDGREN \& K. TONDERSKI. 2007. Denitrification in wetlands. In, H. BOTHE, S. J. FERGUSON \& W. E. NEWTON (eds.), Biology of the Nitrogen Cycle. Elsevier, Amsterdam, The Netherlands. pp. 359-367.

XU, H., H. W. PAERL, G. ZHU, B. QIN, N. S. HALL \& M. ZHU. 2017. Long-term nutrient trends and harmful cyanobacterial bloom potential in hypertrophic Lake Taihu, China. Hydrobiologia, 787: 229-242.

ZEDLER, J. B. \& S. KERCHER. 2005. Wetland resources, status, trends, ecosystem services, and restorability. Annual Review of Environment and Resources, 30: 39-74. 